\title{
MUHASEBEDE KARȘILIKLAR*
}

\author{
Prof. Dr. Orhan SEVILENGÜL**
}

Derleme Makalesi/Compilation Article

Muhasebe Bilim Dünyası Dergisi

Mart 2020, 22(1), 21-37

ÖZ

Birçok terim gibi karşılık teriminin de farklı alanlarda, anlam ve kapsam açısından, farklı biçimlerde kullanılması doğaldır. Doğal olmayan aynı alandaki genel düzenlemelerin ve yayınların, karşılık ve karşılık ayırma konusunu birbirinden farklı ve çelişkili şekilde yansıtarak kargaşa yaratmasıdır. Bu çalışmanın amacı, karşılık terimine ilişkin olarak temel dayanaklardaki açıklamaları değerlendirerek bu kargaşanın giderilmesine katkıda bulunmaktır. Çalışmada; Türk Ticaret Kanunu, Vergi Usul Kanunu, Tekdüzen Muhasebe Sistemi, Türkiye Muhasebe Standartları ile bu konudaki uygulamaları ile özellik gösteren bankacılık ve sigortacılık işletmelerinin muhasebe sistemlerindeki düzenlemeler çeşitli açılardan incelenmiş, yapılan tespitler çalışmanın sonunda bir liste halinde sunulmuştur.

Anahtar Kelime: Muhasebe, Karşılıklar

Jel Sınıflandırması: M40, M41

\section{PROVISIONS IN ACCOUNTING}

\section{ABSTRACT}

In terms of meaning and scope, it is normal that the provision term like many other terms can be used in different fields and forms. Creating turmoil by reflecting provision and making provision in a different and contradictory way by general regulations and publications in the same field is not normal. The aim of this study is to contribute to the elimination of this turmoil by evaluating the explanations in the foundation related with the term provision. In this study Turkish Commercial Code, Tax Procedure Law, Uniform Accounting Standards, Turkish Accounting Standards, and arrangements in the accounting systems of banking and insurance companies were investigated from various aspects and the findings were presented in a list at the end of the study.

Keywords: Accounting, Provisions

Jel Classification: M40, M41

\footnotetext{
* Makale geliş tarihi: 29.08.2018; kabul tarihi: 09.01.2020

${ }^{* *}$ Başkent Üniversitesi Öğretim Üyesi, osevilen@baskent.edu.tr, iD orcid.org/0000-0001-5188-4262 Atıf (Citation): Sevilengül, O. (2020). Muhasebede karş1lıklar. Muhasebe Bilim Dünyası Dergisi. 22(1), 21-37. https://doi.org/10.31460/mbdd.410916
} 


\section{GIRIŞ}

Sözlüklerde "karşıllı" teriminin, birbirinden çok farklı anlamdaki, sözcük ya da tanım ile eşleştirilmesi, bir kısım terimler yerine de karşılık teriminin kullanılmasına, böylece muhasebe alanında kavram karışıklı̆̆ yaratılmasına neden olabilmektedir. ${ }^{1}$

Vergi Usul Kanunu'ndaki şüpheli alacaklar ve karş1lığına ilişkin 323. maddenin bulunduğu bölümün başlığının "Alacaklarda ve Sermayede Amortisman" olması da karşılık terimi yerine amortisman teriminin bir yasa da bile kullanılabildiğini göstermektedir.

TMS 37- Karşılıklar, Koşullu Borçlar ve Koşullu Varlıklar Standardı'nda, bu kargaşaya, aşağıdaki gibi bir ifadeyle, değinilmesi dikkat çekicidir. "Bazı ülkelerde, "karşılıklar” terimi, amortisman, varlıklarda değer düşüklüğü ve şüpheli alacaklar gibi kavramları ifade etmek için de kullanılmaktadır. Bunlar, varlıkların defter değerinde yapılan değişikliklere ilişskin düzeltmelerdir (ayarlamalar) ve bu standardın konusuna girmezler" (prg.7).

Aslında karmaşanın bunlarla sınırlı olmadığı, aynı standartta karşılıkların ticari borçlar ve tahakkuklar gibi diğer yükümlülüklerden neden ayrıldığının, bu iki yükümlülüğün tanımının yapılarak, anlatılmasında da görülmektedir (prg 11).

Muhasebe konusundaki yayınlarda veya eğitiminde karşl1ık kavramının anlamına ve temel çıkış noktalarına değinilmeden, kayıt yapılmasına girişilmesinin de bu kargaşaya katkıda bulunduğu gözlenmektedir.

Bu çalışmanın amacı;

-karşılık ve karşılık ayırma terimlerinin muhasebedeki anlamı,

-karşılık ayırma işleminin dayandığı temel çıkış noktaları,

-özellik gösteren sektörlerde bu terimin farklı kullanımları

hususlarına netlik kazandırmaktır.

Çalışma, karşılık konusuna ilişkin bir kısım metinlerin incelenmesi ve irdelenmesi ile terimin doğru kullanılması için bir kısım tespitlerin ve önerilerin ortaya konulması şeklinde yürütülmüştür.

\footnotetext{
${ }^{1}$ Muhasebe alanında kullanılan karşılık terimine ilişkin bazı tanımlar; hesaben yapılan aktarma, gider, ayrılan tutar, alınan tedbir, ayrllan para gibi sözcüklerle bitebilmektedir.
} 


\section{KARȘILIK TERIMININ ANLAMI}

Muhasebede giderler:

- ödemede bulunulması,

- mevcut varlıkların faydalarının tüketilmesi,

- borçlanılması,

- alacaklısının isteme hakkı gelecekte ortaya çıkacak bir borcun giderlere eklenmesi (tahakkuk),

- miktarı ve/veya doğuşu konusunda belirsizlik bulunan bir gider veya zararın ortaya çıkması

\section{(karşılık ayırma)}

şeklindeki olguların birisi ile ortaya çıkmaktadır.

Giderlerin oluşma şekillerine ilişkin yukarıdaki listede yer alan "karşılık ayırma" yoluyla gider yazma şeklindeki uygulama aşağıda, ilgili düzenlemeler ışığında, incelenecektir.

Muhasebe alanındaki birçok terim (aktif-pasif, rezerv, amortisman, avans, sukont vb.) dilimize Fransızcadan aktarılarak kullanılagelmiştir. Provizyon sözcüğü de bunlardan biridir. Söz konusu sözcük, kullanıldığı yere göre, çok değişik anlamlara gelebilmektedir.

Genel nitelikli sözlüklerde karşılık (provizyon) sözcügünü anlamı veya karşıtı olarak yer alan ifade veya sözcüklerin (Bir çekin para olarak karşıllı̆̆, Bir iş için ayrılmış para, Ödenek, Tahsisat, Cevap, Bedel vb.) muhasebedeki karşıllk terimi ile bir benzerliği bulunmamaktadır. Bu nedenle genel sözlüklerdeki sözcükler yerine (diğer mesleki alanlarda olduğu gibi) karşllık teriminin² muhasebenin kuramsal yapısı ve işlemin özellikleri göz önünde tutularak tanımlanması ve kullanılması gerekmektedir.

Karşılık teriminin çeşitli düzenlemelerdeki kullanımları aşağıda açıklanmış ve değerlendirilmiştir.

\section{YASAL DÜZENLEMELERDE KARŞILIKLAR}

Karşılık terimine değinilen başlıca iki yasadaki hükümler aşağıda incelenmiştir.

\subsection{Türk Ticaret Kanunu’nda Karşılıklar}

Karş1lıklar konusuna, 6102 sayılı Türk Ticaret Kanunu'nun 75. maddesinde değinilmektedir. Söz konusu maddenin "Gerçekleşmesi şüpheli yükümlülük ve askıdaki işlemlerden doğabilecek muhtelif kayıplar için Türkiye Muhasebe Standartlarında öngörülen kurallara göre karşıllk ayrılır" şeklindeki ifadesinde; bir yandan karşılık ayrılmasının standartlardaki kurallara göre yapılacağı hüküm altına

\footnotetext{
${ }^{2}$ Terim: Bir bilim, sanat, meslek dalıyla ya da bir konuyla ilgili özel ve belirli bir kavram olan sözcük
} 
alınırken öte yandan karşılıklara ilişkin standarttan farklı bir tanım verilmesi dikkat çekicidir. Çünkü “askıdaki işlemlerden doğabilecek kayıplar" ifadesi ne ilgili standartta ne de diğer düzenlemelerde yer almaktadir.

\subsection{Vergi Usul Kanunu'nda Karşılıklar}

213 sayılı Vergi Usul Kanunu'nun, değerleme bölümünde, karşılık aşağıdaki gibi tanımlanmaktadır (VUK m.288, prg.1):

"Hasıl olan veya husulü beklenen fakat miktarı katiyetle kestirilemeyen ve teşebbüs için bir borç mahiyetini arz eden belli bazı zararları karşılamak maksadıyla hesaben ayrllan meblağlara karşıllı denir"

Vergi Usul Kanunu’nun (Bu bölümde kısaca "kanun” denilecektir) yürürlüğe girdiği 1950 yılından bu yana söz konusu kanundaki yerini koruyan bu tanım incelendiğinde: çeşitli açılardan muhasebe anlayışıyla, hatta, kanunun diğer maddelerinde yer alan bazı hükümlerle tam uyuşmadığı dikkati çekmektedir.

\subsubsection{Belirsizlik Açısından}

Tanımda, karşı1ık ayırmanın gerekliliği; ortaya çıkan gider veya zararın miktar açısından belirsiz olmasına bağlanmakta, zararın doğmasına ilişkin belirsizliğe ise değinilmemektedir. Oysa ki, Kanunun uygulama maddelerinde, miktar ile birlikte, zararın doğuşuna ilişkin belirsizliğin de karşılık ayırmayı gerektirdiği hususunun yer aldığı görülmektedir. Örneğin Kanunun 323. maddesinde şüpheli (tahsili edilip edilemeyeceği belirsiz) alacakların da karşı1ık konusu edilebileceği belirtilmektedir.

\subsubsection{Kapsam Açısından}

Tanımda yer alan "teşebbüs için borç niteliğinde olması" sınırlaması aktifle ilgili karşı1ıkları tanım dışı bırakmaktadır.

Buna mukabil, Kanunun şüpheli alacaklara ilişkin 323. maddesinde yer alan “....şüpheli alacaklar için değerleme gününün tasarruf değerine göre pasifte karşıllk ayrllabilir” ifadesi uygulamanın varlıkları da kapsadığını göstermektedir. Ayrıca, “değeri düşen mallar”ın değerlemesinde (Kanunda karşılık terimi kullanılmamakla birlikte), esas alınması istenen emsal bedel de belirsizlik içerdiğinden stokun değerinin bilanço günündeki değere indirgenmesi, doğal olarak, karşl1ık ayırma yoluyla gerçekleştirilmektedir.

\subsubsection{Bilançoya Yansıma Açısından}

Kanundaki "Karşıllklar mukayyet değerleriyle pasifleştirmek suretiyle değerlenir." (m.288 prg.2) şeklindeki ifade, sadece borç ve gider karşıllkları için geçerlidir. Vergi Usul Kanunu'nda Maliye Bakanlı̆̆ı'na tanınmış olan yetkiye dayanılarak çıkarılan 1 Sıra No'lu Muhasebe Sistemi Uygulama 
Genel Tebliği ile yürürlüğe konan Tekdüzen Hesap Planı açıklamalarında ve bilanço örneklerinde aktifle ilgili karşılıkların bilançoda ilgili varlık kaleminden indirim biçiminde gösterilmesi esası yer aldığına göre, Kanundaki karşılıkların pasifte raporlanmasına ${ }^{3}$ yönelik, bu belirleme gerekli ve geçerli olmaktan çıkmıştır.

\subsubsection{Diğer Terimlerden Ayrılma Bakımından}

Kanundaki; "Amortismanlar hakkindaki özel hükümler mahfuzdur" (m.288 prg.3) hükmü, karşılıklarla amortisman arasında benzerlik kurulmasının olası görüldüğü dönemlerde, karışıklığı önlemek için alınmış bir önlem niteliğindedir.

Varlıklara ilişkin karşılıklarla amortisman işlemi arasında, her iki işlemin de kaydedildiği hesapların aktifi düzenleyici olması dışında, bir benzerlik kurulması mümkün olmadığından (ayrıca bu husus ilgili standartta özellikle vurgulandığından) bu farklılığın, bir yasa hükmüyle, açıklanmasına gerek bulunmamaktadır.

\subsection{5. İsteğe Bağlı Olma Açısından}

Kanun : “..... şüpheli alacaklar için ... karşıllk ayrılabilir.” (m.323 pr.4) hükmü ile karşıllık ayr1lıp ayrılmaması konusunda vergi yükümlüsüne bir seçim hakkı tanımaktadır. Ancak, gerekli karşı1lı̆ın ayrılmaması seçeneğinin benimsenmesi durumunda, ihtiyatllık temel kavramının göz ardı edilmiş olacağı, buna bağlı olarak da finansal tabloların gerçeği yansıtmayacağı açıktır.

\footnotetext{
${ }^{3}$ Vergi Usul Kanunu'ndaki bu hükme uygun şekilde uygulama yapıldığı geçmiş dönemlerde karşılıkların "öz kaynak" sayılıp sayılmayacağı tartışma konusu bile yapılmıştır. Örneğin; o dönemlerde Hazine Müsteşarlı̆̆ı tarafından hazırlanan yatırım indirimi uygulamasında esas alınacak öz kaynaklar tablosunun bir bölümü aşağıdaki gibiydi.
}

ÖZ KAYNAKLAR

A-Ödenmiş Sermaye

........

G-Karşılıklar

-Şüpheli Alacaklar Karşılığı

.......... 


\section{MUHASEBE UYGULAMASININ DAYANDIĞI DÜZENLEMELERDE}

\section{KARŞILIKLAR}

Muhasebe uygulamasının dayanağını oluşturan ve gelişmesine katkıda bulunan düzenlemelerde yer alan karşılık terimi ve uygulaması aşağıda irdelenmiştir.

\subsection{Temel Kavramlarda Karşılıklar}

1 no.lu Muhasebe Uygulama Tebliği’ndeki ihtiyatlılık kavramının açıklamasında yer alan “.....Bu kavramın sonucu olarak işletmeler, muhtemel giderleri ve zararları için karşılık ayırırlar" ibaresi karşılık ayırmanın ihtiyatlı (temkinli) davranmanın gereği olduğu vurgulanmaktadır.

Karşı1lık ayırma işleminin cari dönem içinde ortaya çıkan bir olay veya durum nedeniyle gelecekte kesinleşebilecek bir gider veya zararı, doğduğu döneme çektiği için, dolaylı olarak dönemsellik kavramı (tahakkuk esası) ile de ilgili olduğu söylenebilir.

\subsection{Genel Kabul Görmüş Muhasebe İlkelerinde Karşılıklar}

Karşılık terimine değinilen genel kabul görmüş muhasebe ilkeleri aşağıda incelenmiştir.

\subsubsection{Gelir Tablosu İlkelerinde Karşılıklar}

a) İlke/1-g: "Karşılıklar, işletmenin kârını keyfî bir şekilde azaltmak veya bir döneme ait kârı diğer dönemlere aktarmak amacıyla kullanılmamalıdır" ifadesinde; karşılığı gereğinden az ya da gereğinden çok ayırarak, kârın istenen tutarda oluşturulmasında karşılığın bir araç olarak kullanılmasının bu ilkeye aykırı olduğu vurgulanmaktadır.

b) İlke/1-1: “.... şarta bağlı olaylardan kaynaklanan, makul bir şekilde gerçeğe yakın olarak tahmin edilebilen gider ve zararlar, tahakkuk ettirilerek gelir tablosuna yansittlır.)" ilkesine göre karşıllık ayırma işlemi için olası gider veya zararın gerçeğe yakın şekilde tahmin edilebilmesi gerekir (Bu özelliği taşımayan riskler finansal tablo dip notlarında açıklanır).

\subsubsection{Bilanço İlkelerinde Karşılıklar}

a) İlke/2-a.3: "Bilançoda varlıkları, bilanço tarihindeki gerçeğe uygun değeriyle gösterebilmek için değer düşüklüklerini göstererek ${ }^{4}$ karşılıkların ayrılması zorunludur.” ilkesine göre karşılık ayırma; (Vergi Usul Kanunu'ndan farklı olarak) yapılması isteğe bağgl değil, zorunlu bir değerleme işlemidir.

b) İlke/2-b.3: “....işletmenin bilinen ve tutarları uygun olarak tahmin edilebilen bütün yabancı kaynakları kaylt ve tespit edilmeli ve bilançoda gösterilmelidir" ilkesinde, tahminden söz edildiğine göre, karşılık terimi kullanılmadan “aktifle ilgisiz” karşılıklar tanımlanmaktadır. Çünkü, kesin nitelikli

\footnotetext{
${ }^{4}$ Sözcük “gösterecek” olmalıdır.
} 
yabancı kaynakların, bilanço dışında bırakılması söz konusu olmadığına göre, ilkede kesin olmayan yabancı kaynakların (yükümlülüklerin) kastedildiği açıktır.

c) İlke/2-c.5: “...Kâr yedekleri yasal, statü ve olağanüstü yedekler ile yedek niteliğindeki karşılıklar, özel fonlar gibi işletme faaliyetleri sonucu elde edilen kârların dağıtılmamış kısmını içerir." Karşılıklar, gider veya zarar yazılarak oluşturulduğuna göre, dağıtılmamış kârdan ayrılan yedekler arasında sayılması ve ona göre rapor edilmesi teknik olarak doğru değildir. ${ }^{5}$ Zira bir kalemin karşı1ık veya yedek olmasını belirleyen özellik benzerlik değil; birini dönem gelirinden diğerinin ise net kârdan indirilerek oluşturulmasıdır.

\subsection{Türkiye Muhasebe Standartlarında Karşılıklar}

TMS 37 Karşıllıklar, Koşullu Borçlar ve Koşullu Varlıklar Standardı'ında (prg.10) karşılık aşağıdaki gibi tanımlanmaktadır.

\section{"Karşılık, gerçekleşme zamanı veya tutarı belli olmayan yükümlülüktür."}

Bu tanım ile yü̈kümlülük teriminin standarttaki tanımı ile birleştirilerek şöyle bütünleşik bir tanım elde edilebilir:

Karşıllı; Geçmiş olaylardan kaynaklanan ve ifası halinde ekonomik fayda içeren kaynakların işletmeden çıkmasına neden olacak; gerçekleşme zamanı veya tutarı belli olmayan yükümlülüktür.

Yukarıdaki esasları göz önünde tutarak aktifle ilgili ve ilgisiz karşılıkları kapsayan aşağıdaki gibi bir tanımlama yapmak da mümkündür.

Karşıllklar, bir işletmenin yakın ya da uzak gelecekteki bir zamanda katlanmak zorunda kalabileceği; tutarı tahmin edilebilen, ancak doğup doğmayacă̆ı belirsiz olan yükümlülükler ile varlıklarda meydana gelebileceği öngörülen değer azalmalarıdır

Standarttaki karşılık tanımı (Vergi Usul Kanunu'ndaki tanım gibi) sadece yükümlülük karşılıklarını kapsamaktadır. Ancak, diğer standartlar incelendiğinde, aktifle ilgili karşıllkların da bu standartlarda yer aldığı görülmektedir. Örneğin; TMS:2 Stoklar Standardı'nda (prg.28); stokların kullanılma veya satılma aşamasında elde edilecek tutarın maliyetinin altında kalması halinde "stok değer düşüklüğü karşıllı̆g " ayrılması ilkesi yer almaktadır. Bu nedenle, ilgili standartların bütün halinde karşılıklar konusunu düzenlediği söylenebilir. ${ }^{6}$

\footnotetext{
${ }^{5}$ Kesinleşmemiş bir yükümlülüğü anlatan "karşılık" ile öz kaynaklar kalemleri arasında bir aktarmayı gösteren "yedekler" birbirinden tamamen farklı olduğuna göre bazı yedeklere "karşılık nitelikli” özelliği yüklenmesi uygun olmamaktadır.

${ }^{6}$ Başbakanlık Yüksek Denetleme Kurulu'nun 1971 yılında yayımlanan Denetleme Kılavuzu'nda gider ve zarar karşıllkları için "Karşllkklar, bilançonun aktifinde yer alan klymetleri gerçek değerine irca etmek veya bilançonun
} 


\subsubsection{Temel Özellik}

Standartta da; karşılık için temel özelliğin "gerçekleşme zamanı veya tutarındaki belirsizlik" olduğu ve bunun, karşıllı̆ı benzer işlemlerden ayırma, ölçütünü oluşturduğu vurgulanmaktadır (prg.1). Buna göre; belirsizlik içermeyen, ortaya çıkması gelecekteki bazı olayların gerçekleşmesine bağlı olan veya miktarı konusunda sağlıkı bir tahminde bulunulamayan yükümlülükler (koşullu borçlar) karşılık konusunun dışında kalır.

\subsubsection{Gereklilik}

Standarda göre; karşılık ayrılması zorunlu bir işlemdir. Aşağıdaki koşulların varlığı karşılık ayrılmasını gerekli kılar (prg.14).

- geçmişte ortaya çıkmış bir olaydan kaynaklanan (İşletmeden istenen bir tazminata ilişkin olarak dava açılması gibi) bir yükümlülüğün mevcut olması,

- yükümlülügün yerine getirilmesi için bir ekonomik değerin işletmeden çıkmasının (tazminat ödenmesi gibi) muhtemel olmas1,

- yükümlülük tutarının güvenilir bir biçimde tahmin edilebilmesi (aksi halde koşullu borç olacağından bilançoda yer almayacaktır).

\subsubsection{Karşılık Miktarı- Paranın Zaman Değeri İlişsisi}

"Paranın zaman değerinin etkisinin önemli olduğu durumlarda karşıllk tutarl, yükümlülüğ̈̈n yerine getirilmesi için gerekeceği tahmin edilen giderlerin bugünkü değeridir”' (prg.45) şeklindeki düzenleme, diğer düzenlemelerden farklı olarak, karşılık tutarının yükümlülük tutarı kadar olmasını değil, yükümlülügün bilanço gününde yerine getirilmesi halinde ödeme miktarı kadar olmasını esas almaktadir. $^{7}$

aktif ve pasifinde yer almamakla beraber, bilançonun düzenlenişinden önce işletmeye yönelmiş belli bir taahhüt ve yükümlülükten doğacak gider ve zararlar için ayrılır." şeklinde bir tanım yapılmıştır. Başbakanlık Yüksek Denetleme Kurulu Denetleme K1lavuzu, 1971.

${ }^{7}$ Haziran ayı sonunda şüpheli hale geldiği değerlendirilen ve tahminen 5 ay içinde tahsil edileceği öngörülen alacak için, faiz oranın 0,12 olduğu varsayımına göre, ayrılacak karşılık tutarları şöyle hesaplanacaktır.

$\begin{array}{lccc}\begin{array}{l}\text { Değerleme } \\ \text { günü }\end{array} & \begin{array}{l}\text { Dönem } \\ \text { Peşin Değer } \\ \text { (a) }\end{array} & \begin{array}{c}\text { Sonu } \\ \text { Pönem Baş1 Değer } \\ \text { (b) }\end{array} & \begin{array}{c}\text { Ayrılacak } \\ \text { Karş1lk } \\ \text { (a-b) }\end{array} \\ \text { 30 Haziran } & 76.169 & & 76.169 \\ \text { 31 Temmuz } & 76.915 & 76.169 & 746 \\ \text { 31 Ağustos } & 77.676 & 76.915 & 761 \\ \text { 30 Eylül } & 78.427 & 77.676 & 751 \\ \text { 31 Ekim } & 79.193 & 78.427 & 766 \\ \text { 30 Kasım } & 80.000 & 79.193 & 807 \\ & & \text { Toplam } & 80.000\end{array}$




\section{5. ÖZELLIK GÖSTEREN ÇALIŞMA ALANLARINDA KARŞILIKLAR}

$\mathrm{Bu}$ bölümde, karşılık konusunda özellik gösteren işletmeler olarak, bankaların ve sigorta şirketlerinin, asıl faaliyetleri ile ilgili olarak ayırdıkları karşılıklar ele alınacaktır (Asıl faaliyetleri dışındaki karşılık işlemleri, doğal olarak, diğer işletmelerdeki gibi yürütülmektedir).

\subsection{Bankacılıkta Kredi Karşılıkları}

5411 sayılı Bankacılık Kanunu'nun “Karşılıklar ve Teminatlar” başlıklı 53. maddesinde “Bankalar, krediler ve diğer alacaklarla ilgili olarak, doğmuş veya doğması muhtemel zararların karşılanması ve bunlar dışında kalan varlıkların değer azalışları için yeterli düzeyde karşılık ayrılmasına .... ilişkin politikalar oluşturmak ve uygulamak ..... zorundadır." ş̧eklindeki hükmü, tüm varlıkların değer azalmaları için ayrılacak karşılık konusunu düzenlemektedir.

Banka varlıkları arasında yer alan kredilerle ilgili olarak ayrılacak karşılıklar (kredi karşıllıkları) çalışma alanına özgü özellikler taşır.

Kredi karş1lıklarına ilişkin politika ve uygulamalar, Resmi Gazete’nin 22/06/2016 tarihli nüshasında yayımlanan "Kredilerin Sınıflandırılması ve Bunlar İçin Ayrılacak Karşılılara İlişkin Usul ve Esaslar Hakkında Yönetmelik” de düzenlenmiştir.

Söz konusu yönetmelikte, bankaların krediler için TFRS: 9 kapsamında karşı1ık ayırmalarının esas olduğu belirtildikten sonra, TFRS uygulamayan bankalar tarafından karşılık ayrılması konusu ayrıntılı olarak ele alınmaktadır.

Karşı1ıklara ilişkin yönetmeliğin esasları aşağıdaki gibi özetlenebilir.

a) Karşılık Miktarının Belirlenmesine İlişkin Esaslar

Hedef alınan riske göre iki ayrı karşılık türü söz konusudur.

\section{i) Genel Karşılıklar (Kredi Genel Riskleri İçin Karşılıklar)}

$\mathrm{Bu}$ tür karşılıklar; her kredinin, borçluların kredi değerliliği dışındaki, bir kısım genel gelişmelere bağlı olarak da tahsil risk taşıyabileceği düşüncesine dayanır. Henüz kredi bazında belirlenmemiş tahsil risklerine ilişkin olarak; bu tür karşılıkların oranları;

I. Grup: Standart Nitelikli Krediler (tahsilinde gecikme olmamış krediler) üzerinden \% 1,5 ve

II. Grup: Yakın İzlemedeki Krediler (Tahsilinde gecikme olmamasına karşın, bazı göstergelere göre gelecekte olabileceği değerlendirilen) krediler) üzerinden \% 3

olarak belirlenmiştir.

Genel karşılıklar, bilançoda yabancı kaynak olarak raporlanır. 
ii) Krediler Özel Karşılıkları (Kredi Bazında Karşılıklar)

Bu tür karşılıklar, tahsilinde gecikme meydana gelmiş olan kredilerin (donuk krediler) her biri için ayrı hesaplanır. Gecikmenin durumuna göre bu aşamadaki krediler için ayrılacak karşılıkların oranları aşağıdaki tabloda gösterilmiştir. Donuk kredilerin banka için değeri azaldıkça karşılık miktarı artırılır. Kredi, değerini tamamen yitirdiğinde de karşılık oranı yüzde yüze ulaşmış olur.

Tablo 1. Kredi Özel Karşılık Oranları

\begin{tabular}{|c|c|c|c|}
\hline Grup & Grup Ad1 & Kredinin Durumu & Oran \\
\hline III. & $\begin{array}{l}\text { Tahsil İmkânı } \\
\text { Sınırlı Krediler }\end{array}$ & 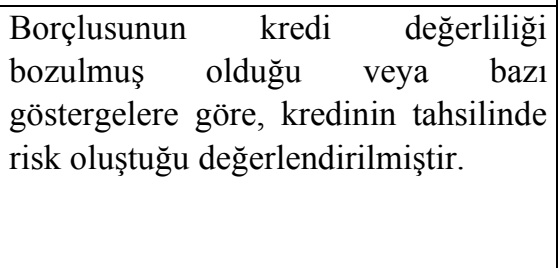 & $\begin{array}{l}\text { Mevcut: } 0 \\
\text { Ayrilacak: } \underline{\mathbf{2 0}} \\
\text { Toplam: } 20\end{array}$ \\
\hline$I V$. & $\begin{array}{l}\text { Tahsili Şüpheli } \\
\text { Krediler }\end{array}$ & $\begin{array}{l}\text { Kredinin ana parasının ve/veya } \\
\text { tahakkuk ettirilmiş eklerinin } \\
\text { edilmesi şüpheli hale gelmiştir. }\end{array}$ & $\begin{array}{l}\text { Mevcut : } 20 \\
\text { Ayrilacak: } \underline{\mathbf{3 0}} \\
\text { Toplam : } 50\end{array}$ \\
\hline$V$. & $\begin{array}{l}\text { Zarar Niteliğindeki } \\
\text { Krediler }\end{array}$ & $\begin{array}{l}\text { Borçlusunun kredi değerliliğini } \\
\text { yitirmiş olmas1 nedeniyle; kredinin } \\
\text { ana parası ve tahakkuk ettirilmiş ekleri } \\
\text { "değersiz alacak" niteliği kazanmıştır. }\end{array}$ & $\begin{array}{l}\text { Mevcut : } 50 \\
\text { Ayrilacak: } \underline{\mathbf{5 0}} \\
\text { Toplam : } 100\end{array}$ \\
\hline
\end{tabular}

Kredi özel karşılıkları, verilen kredi şeklindeki varlıkları bilanço günündeki değerine indirgeyen “aktif nitelikli karşılık” lar olduğundan, krediler toplamından indirim biçiminde raporlanır.

b) Teminatların Riski Karşılama Yeteneğinin Değerlendirilmesine İlişkin Esaslar

Yönetmelikle; teminat gösterilen teminatın nakde çevrilmesi halinde sağlayacağı nakit girişinin teminatın hali hazırdaki değeri ile aynı olmayabileceğinin göz önünde tutulması esası getirilmiştir. Bu yaklaşım uyarınca da teminat türleri 5 grupta toplanmış, her grubun krediyi karşılama derecesi (riski karşılama gücü) oran olarak listelenmiştir. Örneğin; birinci grupta yer alan teminatların (Nakit, mevduat, katılım fonu vb.) riski karşılama oranı \%100 iken, dördüncü grupta yer alan teminatların (ticari işletme rehni, uçak veya gemi ipoteği) yüzde \%60’’ olarak belirlenmiştir. 


\subsection{Sigortacılıkta Teknik Karşılıklar}

5684 sayılı Sigortacılık Kanunu'na dayanılarak çıkarılan ve Resmi Gazete'nin 7/08/2007 tarihli nüshasında yayımlanan "Sigorta ve Reasürans ile Emeklilik Şirketlerinin Teknik Karşıllklarına ve Bunların Yatırılacă̆ı Varlıklara İlişkin Yönetmelik”te sigorta tekniğinin gerektirdiği karşılılıklar “teknik karşılıklar” olarak nitelenmektedir.

Sigortacılıkta teknik karşı1ıklar, sigortacılık iş kolu için hazırlanmış olan kayıt sisteminin özelliğine uygun olarak, ilgili sigorta dalının prim gelirlerinden indirilerek oluşturulur. Bu nedenle hesap planında teknik giderlerin toplandığı gelir tablosu hesapları bulunmamaktadır. ${ }^{8}$

Teknik karşılık türleri aşağıda sıralanmış ve bunların karşılık niteliğini taşıma durumları değerlendirilmiştir.

\subsubsection{Kazanılmamış Primler Karşılığı}

Sigortacılık kayıt sistemine göre, sözleşmenin akdedilmesi sırasında elde edilen prim gelirinin tamamı, dönem ayırımı gözetilmeden, cari dönem geliri olarak kaydedilir. Dönem sonunda gelecek dönemlere ait olan kısım, “Kazanılmamış Primler Karşıllğı” olarak gelecek döneme aktarılır.

Kazanılmamış prim geliri; cari yılda tahsil edilmiş gelirin gelecek dönemlere ait kısmı olduğuna göre, bir "karşıllk" olarak nitelendirilmesi muhasebe tekniği açısından, doğru olmamaktadır. Kazanılmamış prim tutarlarının bilançoda "Gelecek Aylara Ait Gelirler ve Gider Tahakkukları" grubunda raporlanması uygun olur.

\subsubsection{Devam Eden Riskler Karşılığı}

Dönem sonu itibarıyla devam eden sigorta sözleşmelerinde;

-sözleşmenin süresi boyunca üstlenilen risk düzeyi ile primin zamana bağlı dağılımının uyumlu olmamas1 ya da;

-kazanılmamış primlerin sözleşme ile üstlenilen riskleri karşılayamaz durumda olması durumlarında riskin kazanılmamış primler karşılığını aşan miktarı için ayrılan karşılıktır.

\subsubsection{Muallak Tazminat Karşılığı}

Muallak (sonuca bağlanmamış, sürüncemede kalmış) tazminatlar karşılığ1;

\footnotetext{
${ }^{8}$ Sigortacılık Tekdüzen Hesap Planındaki "680 Karşılıklar” hesabı, sigortacılık dışı işlemlerle ilgili karşılıkların izlenmesi için oluşturulmuştur.
} 
-tazminat yükümlülüğü tahakkuk etmiş ve hesaplanmış, ancak dönem sonu itibarılyla fiilen ödenmemiş olması,

-tazminat bedelinin dönem sonu itibarıyla hesaplanamamış olması,

- tazminat yükümlülüğü gerçekleşmiş ancak rapor edilmemiş olması

durumlarında ayrılan karşılıklardan oluşur.

Bunlardan; "tazminat yükümlülügü tahakkuk etmiş ve hesaplanmış, ancak dönem sonu itibartyla fiilen ödenmemiş” tutarlar, karşılık değil, borç, niteliğindedir.

\subsubsection{Matematik Karşılıklar}

Bir yıldan uzun süreli hayat, sağl1k ve ferdi kaza sigorta sözleşmeleri ile üstlenilen yükümlülükler için ayrılan karşı1ıklardır.

Matematik karş1lıklar "aktüeryal karşılıklar" ile "kâr payı karşılıkları" ndan oluşmaktadır.

\subsubsection{Dengeleme Karşılığı}

İzleyen dönemlerde meydana gelebilecek tazminat oranlarındaki dalgalanmaları dengelemek ve katastrofik (felaket nedenli) riskleri karş1lamak üzere tüm sigorta kollarında verilen kredi ve deprem teminatları için ayrılan Genel nitelikli risk karşı1ıklarıdır.

\subsection{6. İkramiye ve İndirimler Karşılığı}

Cari dönemde devam eden poliçelerde yer alan; sigortalıya izleyen dönemlerde, yenilemeye bağlı olmaksızın, bir ikramiye ödenmesi veya yeni poliçede bir indirim yapılması taahhüdü için ayrılan karşl1ıklardır. Dönem gelirlerinden indirilen bu tutarlar aslında karşılık değil, gider tahakkuku niteliğindedir.

\section{DEĞER DÜŞÜKLÜĞÜ KARŞILIKLARININ GIDER VEYA ZARARA MAHSUBU}

Varlık değer düşüklüğü için ayrılan karşılığın kısmen veya tamamen gerçekleşmesi ya da değer düşüklüğü riskinin bütünüyle ortadan kalkması durumunda karşıllğa uygulanacak işlemler konusunda farklı muhasebe uygulamaları yapılabilir.

i. Karşılığın Tamamının İptal Edilmesi Yaklaşımı

Yaklaşım, karşılık yoluyla gider veya zarar yazma işleminin geçici olduğu, gider veya zararın kesinleştiği dönemin gelir tablosunda bütün olarak raporlanması gerektiği anlayışına dayanır. $\mathrm{Bu}$ yaklaşımda, karşılığın tamamı iptal edilir. Kesinleşen gider veya zarar o dönemin ilgili gelir tablosu hesabına borç yazılır. 
ii. Karşılığın Zararı Aşan Kısmının İptal Edilmesi Yaklaşımı

Yaklaşım, gider veya zararın esas olarak riskin ortaya çıktığı döneme ait olduğu, riskin kesinleştiği dönemdeki zarar - karşılık farkını yeni dönemdeki gelişmelerin yarattığı, bu nedenle de farkın o dönem gelir tablosunda yer almasının gerektiği anlayışına dayanır. Bu yaklaşımda, kesinleşen zarar karşılıktan mahsup edilir, varsa, kalan karşılık iptal edilir.

iii. Karşıllğın Varlığın Değerini Netleştirmesi Yaklaşımı

Bu yaklaşım; varlığın dönem başındaki defter değerinin; kayıtlı bedel ile karşılık arasındaki farktan oluştuğu gerçeğinin göz önünde tutulması gerektiği anlayışına dayanır. Bu yaklaşımda, izleyen dönemdeki işlem sırasında önce varlığın kayıtlı değerinden karşılık indirilerek varlı̆̆ın net değeri bulunur. İşlemin yarattı̆̆ı nakit girişi (satış, tahsil vb. yoluyla) ile bu değer karşılaştırılır, fark işlem kârı ya da zararı olarak muhasebeleştirilir.

İlk İki yaklaşım yükümlülükler için de geçerlidir.

Üç yaklaşıma göre yapılacak kayıtların sonuçlarının farklılığı aşağıda bir örnekle (Şüpheli alacak tutarının $100 \mathrm{TL}$, karşılığın 25 TL ve izleyen dönemde tahsilatın 70 TL olduğu varsayımına göre) ortaya konulmaya çalışılmıştır.

Tablo:2 Karşılık Mahsubu Yaklaşımları

\begin{tabular}{|c|c|c|c|}
\hline Yaklaşım & i. & ii. & iii. \\
\hline Varlık Bedeli & 100 & 100 & -25 \\
\hline Karşılık & -25 & -25 & 75 \\
\hline Net değer & 75 & 75 & 70 \\
\hline Nakit Girişi & 70 & $700-70=30$ \\
\hline Sonuçta Oluşan Zarar & $100-70=30$ & $100-70=30$ & 20 \\
\hline Maliyetten İndirilen Karş. & & & \\
\hline Zarara Mahsup & -75 & 20 & 5 \\
\hline Dönem İşlem Kârı / zararı & 25 & & \\
\hline Konusu Kalmayan Karş. & & & \\
\hline
\end{tabular}




\begin{tabular}{|c|c|c|c|c|}
\hline & Tahsil & Tahsil & Alacak tutarı & 100 \\
\hline \multirow[t]{4}{*}{ Gelir Tablosuna Yansıma } & Alacak tutarı & Alacak tutarı & Karşılık Tutarı & -25 \\
\hline & Tahsil zararı & Tahsil zararı & Defter değeri & 75 \\
\hline & Karş1lık iptal kârı $\underline{+25}$ & Karş. zarara mah. +25 & Tahsil & -70 \\
\hline & Dön. Kârına etki -5 & Dön. Kârına etki -5 & Dön. Kârına etki & -5 \\
\hline
\end{tabular}

TMS 2 Stoklar Standardı’nda (prg.34) “Íptal edilen stok değer düşüklüğ̈̈ karşılık tutarı satış maliyetini azaltacak şekilde muhasebeleştirilir" ifadesinden üçüncü yaklaşımın benimsendiği anlaşılmaktadır.

Tekdüzen Hesap Planındaki varlıklara ilişkin hesapların açıklamalarında ise bir kısım farklılıklar ve tutarsızlıklar gözlenmektedir.

Örneğin; 129 Şüpheli Alacaklar Karşılığı hesabının işleyişine ilişkin açıklamada yer alan “.....Ş̈̈pheli alacağın tahsiline bağll olarak tahmin olunan zararın kısmen ya da tamamen gerçekleşmemesi halinde, gerçekleşmeyen kısım 644 Konusu Kalmayan Karşılıklar Hesabı alacağına devredilerek bu hesaba borç kaydedilir" ifadesinden, standarttan farklı olarak, ikinci yaklaşımın benimsendiği anlaşılmaktadır. .

158 Stok Değer Düşüklüğü Karşılığı hesabının işleyişine ilişkin açıklamada ise “...Karşıllk ayrılan stok kaleminin işletme içinde kullanılması ya da satılması halinde; ilgili stok hesabının alacă̆ ile karşılaş̧ırılarak, daha önce ayrılan karşılık "644 Konusu Kalmayan Karşıllılar Hesabına" aktarılarak kapatılır" ifadesinde hem stok bedeline mahsup edilmesinden hem de konusu kalmayan karşılıklar hesabına aktarılmasından söz edilmesi tutarlı değildir. Karşılık miktarı stokun bedelinden büyük olamayacağına göre, "644 Konusu Kalmayan Karşılıklar Hesabına" aktarılacak karşılık kalmayacağı açıktır. Kalan karşılı̆̆ın 644 no.lu hesaba aktarılacağı şeklindeki ifadenin uygulamada göz ardı edildiği görülmektedir.

Varlık değer düşüklüğü karşılılıklarına, izleyen dönemlerde uygulanacak işlemlerin birbiri ile tutarlı hale getirilmesi uygun olacaktır. 


\section{SONUÇ VE DEĞERLENDİRME}

Karşı1lık ve karşılık ayırma terimlerine ilişkin inceleme, irdeleme ve eleştirme ${ }^{9}$ sonuçları aşağıdaki gibi özetlenebilir.

Tanım: Yükümlülük karşıllğının tanımı, ilgili Türkiye Muhasebe Standardı'nda, niteliğine uygun biçimde, yapılmış bulunmaktadır. Tekdüzen Muhasebe Sistemi'nde ve mesleki literatürde de bu tanımlamadan hareket edilmesi karmaşaya son verecek, eğitime de katkı sağlayacaktır.

Amaç: Karşılık ayırmanın amacı; aktife ilişkin bir kısım değer azalmaları ile kesinleşmemiş ödeme yükümlülüklerini dönem sonuçlarına yansıtmaktır. Bu amaç; varlık, kaynak ve dönem kârının doğru raporlanabilmesi için karşılık ayırmayı zorunlu kılar.

Karşılığın, olması gerekenden, fazla ayrılması yoluyla dönem kârının gelecek döneme aktarılması (gizli yedek akçe oluşturulması) için bir araç olarak kullanılması işlemin amacının dışındadır.

İşlemin Niteliğ̈i: Aktifle ilgili karşıllk ayrılması, değerleme işlemi, gider ve zararlar için karşıllk ayrılması ise bir yükümlülü̆ğ̈̈n (kesinleşmemiş borcun) kayıtlarda oluşturulması işlemidir.

Kesinleşmesinde belirsizlik olan bir gider veya zararın dönemin kârından indirilmesi ile aynı gider veya zararın doğrudan gider yazılması dönem kârını etkilemez. Ancak karşılığın ayrıldığı dönemde karşılık kalemlerindeki tutarlar; gider yazılmasına ilişkin olgunun henüz belirsizlik içerdiğini yani, kısmen veya tamamen gecçekleşmeme olasıllğının da bulunduğunu finansal tablo kullanıcılarının dikkatine sunar.

Muhasebeleştirme: Varlık azalmasında: gider veya zarar kesinse; ilgili varlık hesabı, kesin değilse varlık grubunda, indirim olarak yer alan, bir karşılık hesabı alacaklanır. Yükümlülük artışında: artış kesinse; bir borç hesabı, kesin değilse; bir gider karşıllğ̆ hesabı alacaklanır.

Finansal Etki: Karşıl1k ayırma işlemi, dönem kârı üzerinden ödenecek vergiyi (kanunen kabul edilir nitelikte olmak kaydıyla) ve dağıtılacak kâr payını azaltmak yoluyla işletmeden fon çıkışını öteler. Bu nedenle finansal tedbir niteliği de taşır.

Kapsam: Bazı düzenlemelerdeki ve kaynaklardaki, karşılıkların pasifte yer alacağı ifadesi sadece gider ve zarar karşılıkları için doğrudur. Varlıkların değerlemesi aşmasında ortaya çıkan riskler için karşılık ayrılması konusu, ilgili varlığa ilişkin düzenlemelerde yer alır.

\footnotetext{
${ }^{9}$ İnceleme-irdeleme-eleştirme sözcükleri aşağıdaki anlamlarda kullanılmıştır: Inceleme: bir konuyu ele alıp özelliklerini, ayrıntılarını özenle anlamaya çalışmak. Irdeleme: bir konunun incelenmesi ve eleştirilmesi gereken bütün yönlerini ortaya koymak. Eleştirme: bir düşüncenin, bir yargının doğru ve yanlışlığını ortaya koymak için onu eleştirel bir yaklaşımla incelemek
} 
Kredi Karşılıkları: Banka işletmelerinin verilen kredi şeklindeki varlık grubunu bilanço günündeki değerine indirgeyen "aktif nitelikli" karşılıklara ilişkin yönetmelikte yer alan;

-kredi riskinin büyümesine paralel olarak karşılık miktarının artırılmasına ve

-teminatların riski karşılama gücünün hesaba katılmasına

dair düzenlemeler, genel uygulamada da göz önünde tutulması gereken, hususlardır.

Karşılığın Mahsubu: Tekdüzen Hesap Planındaki varlıklar için ayrılmış karşıllıkların gider ve zararlara mahsup edilmesine ilişkin açıklamaların tüm varlıklar için tekdüzen hale getirilmesi, ayrıca; yükümlülüklere ilişkin karşlık hesaplarının işleyişine dair açıklamalara da mahsup işleminin eklenmesi uygun olacaktır.

Paranın zaman değeri: Yükümlülük karşılıklarının miktarının hesaplanmasında paranın zaman değerinin göz önünde tutulmasına yönelik standart hükmünün, yeni bir yaklaşım olarak, diğer düzenlemelere ve uygulamalara yansitılması uygun olacaktır.

Tekdüzen hesap planı: Tekdüzen hesap çerçevesi ve hesap planı yeni ihtiyaçlar göz önünde tutularak, yeniden düzenlenmeli, bu arada mevcut hesapların açıklamalarındaki birbiri ile ve standartlarla olan çelişkileri de giderilmelidir.

\section{YAZARIN BEYANI}

$\mathrm{Bu}$ çalışmada, Araştırma ve Yayın Etiğine uyulmuştur, çıkar çatışması bulunmamaktadır ve de bu çalışma için finansal destek alınmamıştır.

\section{AUTHOR'S DECLARATION}

This paper complies with Research and Publication Ethics, has no conflict of interest to declare, and has received no financial support.

\section{KAYNAKÇA}

1 sayılı Muhasebe Uygulama Genel Tebliği www.mevzuat.gov.tr./mevzuatMetin (Erişim Tarihi:30.10.2017)

Sigortacılık Tekdüzen Hesap Planı ve İzahnamesi Hakkında Teblig. https.www.tsb.org.tr.sigortacılıkhesap-plani (Erişim Tarihi:10.12.2017) 
Orhan SEVİLENGÜL

Muhasebe Bilim Dünyası Dergisi, 2020, 22(1), 21-37

Tekdüzen Hesap Planı ve İzahnamesi Hakkında Tebliğ. www.tbb.org.tr/Dosyalar/Düzenlemeler/Bankaların/THP-Tebliğ (Erişim Tarihi:10.12.2017)

Türk Ticaret Kanunu. www.mevzuat.gov.tr./mevzuatMetin (Erişim Tarihi:10.12.2017)

Türkiye Finansal Raporlama Standartları. www.kgk.gov.tr./content/detail (Erişim Tarihi: 20.12.2017)

Vergi Usul Kanunu. mevzuat.gov.tr./mevzuatMetin (Erişim Tarihi: 15.12.2017) 